\title{
Microbial Respiration as Indicator of Soil Quality of Different Land Uses in Cienda, Gabas, Baybay City, Leyte
}

\author{
Jessa May T. Malanguis', Cheryl C. Batistel ${ }^{1 *}$ and Marlito Jose M. Bande ${ }^{2}$
}

\begin{abstract}
Land use conversion affects soil ecosystem quality and balance, which can be reflected by microbial activities. This study was conducted to assess the effectiveness of microbial respiration as indicator of soil quality of different land uses, reforestation site, agricultural land and grassland, in Cienda, Gabas, Baybay City, Leyte. The amount of $\mathrm{CO}_{2}$ evolved after one, three and seven days of incubation was used to determine microbial respiration rate of different land uses and across relief. Relationship between microbial respiration on $\mathrm{pH}$, organic matter, total nitrogen, and moisture content at field capacity were also examined.

Results revealed that microbial respiration varies significantly among land uses with the highest rate observed in grassland while the lowest was in the reforestation site. Across relief, amount of $\mathrm{CO}_{2}$ released was significantly higher in the lower slope compared to the upper and the middle. The process tends to be significantly influenced by soil organic matter and moisture content. Results suggest that there is an inverse relationship between microbial respiration and organic matter, and a direct relationship with moisture content. High soil respiration in the grassland and in the lower topographic relief implies that the soil organic matter is converted into inorganic forms which are available for uptake by plants. A significant interaction between land use types and relief was also observed in both organic matter and moisture content leading enhanced microbial respiration. Land use and relief showed no significant effect on total nitrogen and soil pH.
\end{abstract}

Keywords: microbial respiration, soil quality, land uses, organic matter, decomposition

\section{INTRODUCTION}

Microorganisms abound in the soil and are critical to ecosystem processes such as decomposition of organic residues and recycling of soil nutrients

\footnotetext{
${ }^{1}$ Department of Biological Sciences, College of Arts and Sciences, Visayas State University, Visca, 6521A Baybay City, Philipines

${ }^{2}$ Institute of Tropical Ecology and Environmental Management, College of Forestry and Environmental Science, Visayas State University, Visca, 6521-A Baybay City, Philipines
}

* Corresponding Author. Address: Department of Biological Sciences, Visayas State University, Visca, Baybay City Leyte 6521A Philippines E-mail: cheryl.batistel@vsu.edu.ph DOI: $10.32945 /$ atr3925.2017 
(Magdoff \& Van Es 2001). Their population in the soil changes rapidly as soil organic matter (SOM) products are added, consumed, and recycled. Nonetheless, soil microorganisms exist in large numbers as long as there is carbon source for energy (Hoorman \& Islam 2010). Being very sensitive to changes in soil conditions, microorganisms can reflect reliable outcomes and results to any soil quality changes even at a shorter period compared to any other parameters (Wolters \& Schaefer 1994, Pankhurst et al 1997). Accordingly, the change in land use can alter both the rate and direction of natural processes (Turner et al 2001), including the soil equilibrium which could be disturbed easily.

Microbial respiration is vital in maintaining soil ecosystem. This oxidative process occurs within living cells, which releases chemical energy of organic molecules in a series of metabolic steps, involving the consumption of oxygen $\left(\mathrm{O}_{2}\right)$ and the liberation of carbon dioxide $\left(\mathrm{CO}_{2}\right)$ and water $\left(\mathrm{H}_{2} \mathrm{O}\right)$. Among the various organisms in the soil, microbes play a fundamental part in the decomposition of organic matter which entails the highest possible source of $\mathrm{CO}_{2}$ available for the soil (Pankhurst et al 1997). Through their acquisition of carbon and nutrients for growth, microbial biomass in soils constitutes an important sink and source of essential plant nutrients. Thus, microbial respiration is important for soil health and soil ecosystem sustainability. In order to determine the response of soil as an affected ecosystem, and to evaluate its condition, there is a need to understand and quantify the linkage between microbial response and change in soil processes such as decomposition and nitrogen mineralization.

Over time, many incidents of declining soil microbial respiration as well as soil health have been reported resulting from different human interventions including land use conversion. Many hypothesized that the rate of microbial respiration significantly varies from forestland to grassland to agricultural land (Anderson 2003), however, not much studies had been conducted to prove this claim. Determination of the impact of different land uses on the status of organic matter and nutrient availability on the tropical forests of Leyte was done by Asio et al (1998). Marohn (2006), on the other hand, studied the soil biological activities under different land uses in Leyte. However, the effectiveness of microbial respiration as indicator of soil quality of different land uses and in different topographic relief still needed to be assessed. Therefore, this study was conducted to determine the relationship between microbial respiration on soil organic matter, $\mathrm{pH}$, nitrogen and moisture content at field capacity, and to determine if the rate of microbial respiration varies significantly among different land uses and topographic relief.

\section{MATERIALS AND METHODS}

\section{Site Description}

The study was conducted in the reforestation site, coconut land, and grassland areas in Cienda, Gabas, Baybay City, Leyte. The three land use types were selected because they are adjacent or least very near to each other, a factor in site selection aimed at minimizing heterogeneity of all other environmental factors affecting soil microbial respiration. The selection of land use was based on the usual trend in land use conversion especially in mountainous areas, that is, forest 
agricultural land. Due to the absence of cropland in the area, coconut land was considered, which is also ecologically important considering that 3.52 million hectares or $26 \%$ of the total agricultural land of the Philippines is planted to coconut as of 2015 (PCA 2015).

The reforestation site in Cienda, approximately $10,000 \mathrm{~m}^{2}$, was established in 1996. It is dominated by dipterocarp and fruit tree species including bagtikan (Parashorea malaanonan [Blanco] Merill), white lauan (Shorea contorta S. Vidal), bitanghol (Calophyllum blancoi), yakal saplungan (Hopea plagata [Blanco] Vidal), malakauayan (Podocarpus spp.), rambutan (Nepheliumlappaceum L.), marang (Artocarpus odoratissimus Blanco) and lanzones (Lansium domesticum Correa), which were planted at an average distance of $2 \mathrm{mx} 1 \mathrm{~m}$. Adjacent to it is an agricultural land planted to coconut trees, with an approximate area of $10,000 \mathrm{~m}^{2}$, having undergrowth vegetation including grasses and bushes. Adjacent to the coconut land is grassland ecosystem, with an estimated area of $7,000 \mathrm{~m}^{2}$, dominated by creeping grasses such as Paspalum sp.

\section{Soil Sample Collection and Preparation}

In each land use, three sampling points were randomly selected in the upper, middle and foot slope of the areas with a total of nine sampling points per land use type. The upper, middle and lower topographic positions had an average elevation of 79,77 , and $75 \mathrm{~m}$ above sea level, respectively.

From each sampling point, one kilogram $(\mathrm{kg})$ of bulk soil sample was collected from the topsoil $(0-20 \mathrm{~cm})$ using a soil auger. One hundred grams $(100 \mathrm{~g})$ of fresh soil samples were set aside; clods of soil were broken down but not sieved and roots were removed using forceps for the determination of microbial respiration (Marohn 2006). The remaining soil samples were air-dried and thoroughly mixed. After air-drying, soil clods and aggregates were pulverized with the use of a wooden mallet. Then, these were passed through a $0.425 \mathrm{~mm}$ wire mesh sieve for the determination of soil $\mathrm{pH}$, organic matter content, total nitrogen and moisture content at field capacity.

\section{Soil Analysis}

Soil $\mathrm{pH}$ was analyzed potentiometrically using a soil:water ratio of 1:2.5 (ISRIC 1998). Soil organic matter (SOM) was determined using the Walkley and Black wet combustion method (ISRIC 1998). Total nitrogen content of the soil was determined through micro Kjeldahl method (Jackson 1958). Moisture content at field capacity was determined by measuring fresh weight after soil saturation, and oven-dry weight of the soil (ISRIC 1998).

For microbial respiration, soil samples were prepared for incubation by weighing $100 \mathrm{~g}$ of fresh soil sample collected from $0-20 \mathrm{~cm}$ depth from the three land uses and across reliefs. These were then placed separately in properly labeled, sealed jars and were incubated at room temperature for one, three and seven days incubation period (Marohn 2006). In total, there were 28 jars used in this experiment: 27 for the soils from the three land uses and a control setup with no soil. Incubation was done by putting $15 \mathrm{~mL} 1 \mathrm{~N} \mathrm{NaOH}$ on a beaker which was placed on top of the jars containing the soil. The jars were tightly sealed and after 
Microbial Respiration as Indicator of Soil Quality

(in milligrams) after each incubation period was determined following the method of Alexander (1997) using the formula:

where:

$$
\text { Milligrams } \mathrm{C} \text { or } \mathrm{CO}_{2}=(\mathrm{B}-\mathrm{V}) \mathrm{NE}
$$

$\mathbf{V}=$ volume $(\mathrm{mL})$ of acid to titrate the alkali in the $\mathrm{CO}_{2}$ collectors from treatment to the end point

$\mathbf{B}=$ volume $(\mathrm{mL})$ of acid to titrate the alkali in the $\mathrm{CO}_{2}$ collectors from control (no soil) to the end point

$\mathbf{N}=$ normality of acid

$\mathbf{E}=$ equivalent weight, wherein if data are expressed in terms of carbon $\mathrm{E}=6$, if expressed as $\mathrm{CO}_{2}, \mathrm{E}=22$.

Statistical Analysis

All data were tested for normality and homogeneity using PROC Univariate of Statistical Analysis System version 9.1 (SAS, 2003). PROC GLM (General Linear Model) procedure was initially performed to assess the significant effects of land uses, relief and their interactions on soil organic matter, $\mathrm{pH}$, total nitrogen, soil moisture content at field capacity, and microbial respiration.

The final models for each response variables were analyzed but including only those significant main factors and interaction effects. Duncan Multiple Range Test (DMRT) and least square means (LSD) were carried out to compare treatment means and independent variables with significant variations at $p \leq 0.05$.

\section{RESULTS AND DISCUSSION}

\section{General Characteristics of the Study Site}

The study site lies within $10^{\circ} 43^{\prime} 33.9^{\prime \prime}$ to $10^{\circ} 43^{\prime} 44.2^{\prime \prime}$ North and $124^{\circ} 48^{\prime} 38.4^{\prime \prime}$ to $124^{\circ} 48^{\prime} 45.1^{\prime \prime}$ East. Soil in the area, based on Food and Agriculture Organization (FAO) classification, is dystric nitisol, and of volcanic origin (Marohn 2007) and falls to Type IV climatic category where the rainfall is almost evenly distributed throughout the year (www1.pagasa.dost.gov.ph). Soil climate has been classified as isohyperthermic, i.e. above $22^{\circ} \mathrm{C}$, throughout the year with variation of less than $5^{\circ} \mathrm{C}$ in the $50 \mathrm{~cm}$ depth (Asio 1996).

\section{Soil Properties of Different Land Uses}

SoilpH

Soils from different land uses and across reliefs are acidic. Between land uses, soil had $\mathrm{pH}$ values ranging from $5.10 \pm 0.07$ to $5.13 \pm 0.07$ (Figure $1 \mathrm{~A}$ ), which are insignificantly different $(p=0.92)$. Across reliefs, on the other hand, soil $p H$ values are between $5.01 \pm 0.07$ to $5.24 \pm 0.07$ with the lowest value observed in the middle while the highest was in the upper relief (Figure 1B). 
ANOVA shows that the difference between these values is nearly significant $(p=0.09)$ although DMRT shows that this difference is significant at $p \leq 0.05$. Nevertheless, lower relief showed insignificant difference between upper and middle relief. Insignificant interaction $(p=0.68)$ between land use types and reliefs was also detected. The significant difference in soil pH between the upper and middle topographic positions may be attributed to the amount of litter present in the soil surface with the former having more leaf litters. The decomposition of such can alter soil $\mathrm{pH}$. Increase in leaf litters may cause increase in soil $\mathrm{pH}$ as it enhances $\mathrm{Mg}^{2+}$ and $\mathrm{Ca}^{2+}$ input which can improve the buffering capacity of the soil that compensate the acidifying effect of acidic intermediates and humus compounds (Toth et al 2011). Results suggest that land use type may not have contributed enough to modify significantly the $\mathrm{pH}$ of the soil.

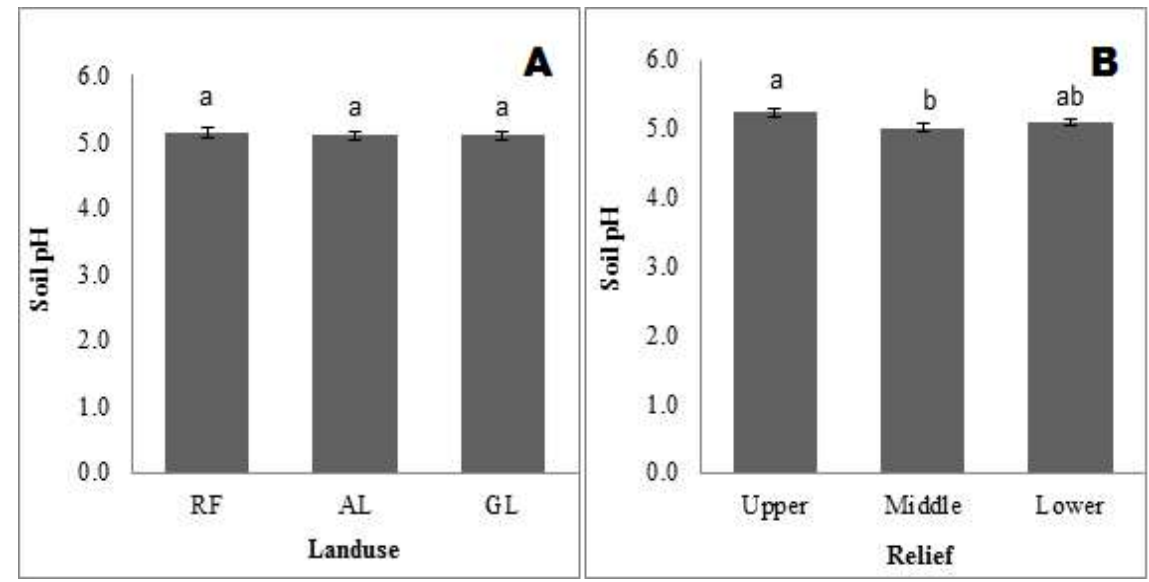

Figure 1. Soil pH of the different land uses (A) and at different reliefs (B) in Cienda, Gabas, Baybay City, Leyte. (Note: RF- Reforestation site; AL- Agricultural land; GL - Grassland. Different letter subscripts $(a-b)$ of the same dependent variables among land use and relief are significantly different at $p \leq 0.05, n=27$ )

\section{Soil Organic Matter}

Results of soil organic matter content in different land use types revealed that the mean soil organic matter content was lowest $(2.18 \% \pm 0.89)$ in grassland while the highest $(3.44 \% \pm 0.89)$ was observed in the reforestation site (Figure $2 \mathrm{~A})$. These values are within the normal range for most mineral soils contain 2 to $10 \%$ organic matter (FAO 2005). Mean SOM values are found significantly different $(p=0.00)$ between land uses. The lowest SOM value in grassland among the three land uses could be explained by the fastest turnover rate of carbon in grassland ecosystem compared to the reforestation site and agricultural land. This implies increased decomposition, which could reduce the carbon available for growing plants and micro-organisms (Davidson \& Janssens 2006) while increasing the inorganic nutrients for plant uptake. The faster decomposition in the grassland could be supported by the morphological characteristics of the dominant grasses in the study site which possess shiny and thinner leaves compared to the tree species in 
Microbial Respiration as Indicator of Soil Quality

the reforestation site, and the coconut in the agricultural land. Morphological features of the grasses suggest thinner cuticle and wax layer on leaf surfaces which otherwise hinder the decomposition process since these substances are resistant to decomposition (Alexander 1977).

SOM across relief ranges from $2.50 \% \pm 0.09$ to $2.89 \% \pm 0.09$ (Figure $2 \mathrm{~B}$ ). ANOVA proves that relief has significant effect $(p=0.01)$ on organic matter. Specifically, the significant difference was found between the lower relief in comparison with the upper and middle relief. Nonetheless, there was no clear difference in OM between upper and middle slopes of the sites. A significant difference $(p=0.05)$ was also observed in the interaction between different land use types and different reliefs. The interaction was specifically observed between agricultural land and grassland in the lower slopes (Figure 3). This could probably be attributed by the similarity in some of the species composition in grassland and agricultural land. The grassland was dominated by Paspalum sp. while in the agricultural land, understorey vegetations include the herbaceous and shrubby as well as grasses, especially Paspalum.

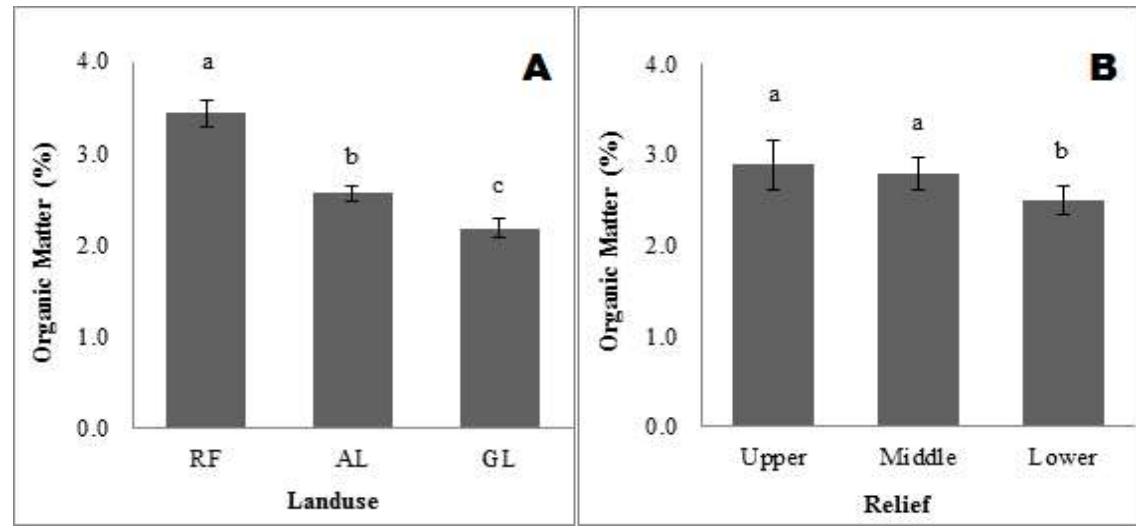

Figure 2. Soil organic matter of the different land uses (A) and at different reliefs (B) in Cienda, Gabas, Baybay City, Leyte. (Note: RF- Reforestation site; AL- Agricultural land; GL - Grassland. Different letter subscripts $(a-b)$ of the same dependent variables among land use and relief are significantly different at $p \leq 0.05, n=27$ )

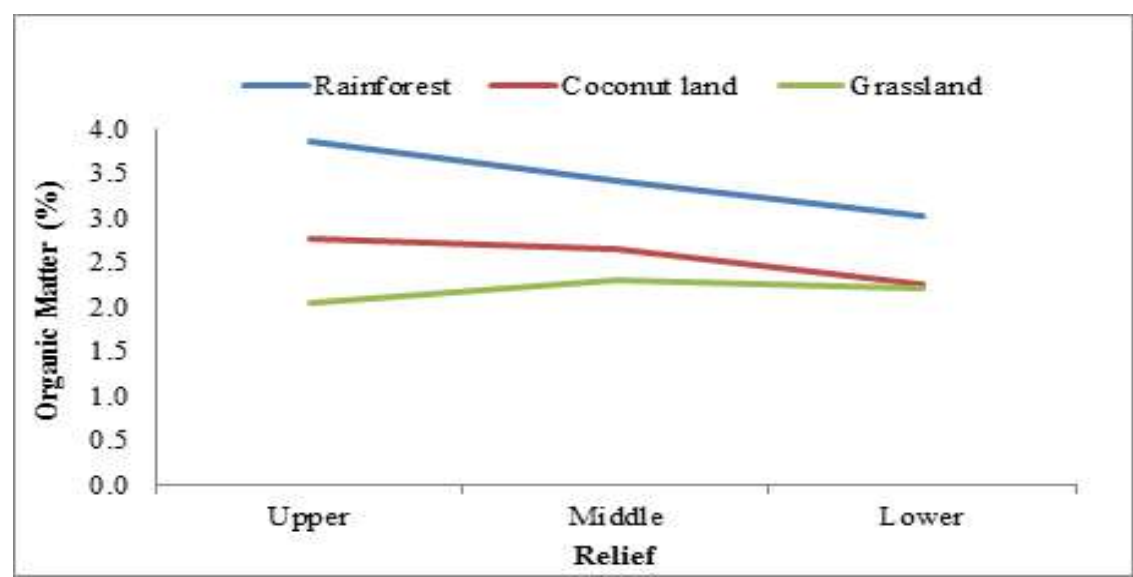

Figure 3. Two factor interaction effect of land use and relief on soil organic matter in Cienda, Gabas, Baybay City, Leyte 


\section{Total Nitrogen}

Total nitrogen does not differ significantly $(p=0.97)$ between land use types and across reliefs. This is clearly because values show only very slight difference between land use types ranging from $0.34 \% \pm 0.02$ in agricultural land to $0.34 \% \pm$ 0.01 in the reforestation site. Total nitrogen slightly varies across reliefs giving no significant difference $(p=0.19)$. Consequently, there is no significant interaction ( $p$ $=0.87$ ) observed in total nitrogen between land use types and reliefs. These values support the study of Asio et al (1998) which reported that the total nitrogen of the topsoil in the reforestation sites in Baybay, Leyte ranges from 0.29 to $0.35 \%$. They also stated that in the same area, lands planted to coconut, in association with bushes, have a total nitrogen of 0.28 to $0.59 \%$. Marohn (2007) also reported around the same values of total nitrogen in the reforestation site in Leyte, Philippines, which are normal for old tropical soils.

\section{Moisture content at field capacity}

Across land use types, moisture content values range from $60.30 \% \pm 1.57$ from reforestation site to $68.24 \% \pm 1.57$ in agricultural land (Figure 4 ). Results revealed that soil moisture content of the reforestation site varied significantly $(p=0.00)$ with that of the agricultural land and grassland (Figure 4A). Results further show that there was no clear variation in moisture content between grassland and agricultural land. Likewise, as can be seen in Figure $4 B$, there was no significant difference $(p=0.66)$ in soil moisture content between reliefs with values ranging from $63.94 \% \pm 1.57$ (upper) to $65.96 \% \pm 1.57$ (middle). However, a significant difference $(p=0.04)$ was observed in the interaction between different land use types and different reliefs (Figure 5). This may be contributed by a similarity in soil texture, which is clayey, in the lower relief in the reforestation site and with that of the agricultural land and grassland, which moisture content across relief do not

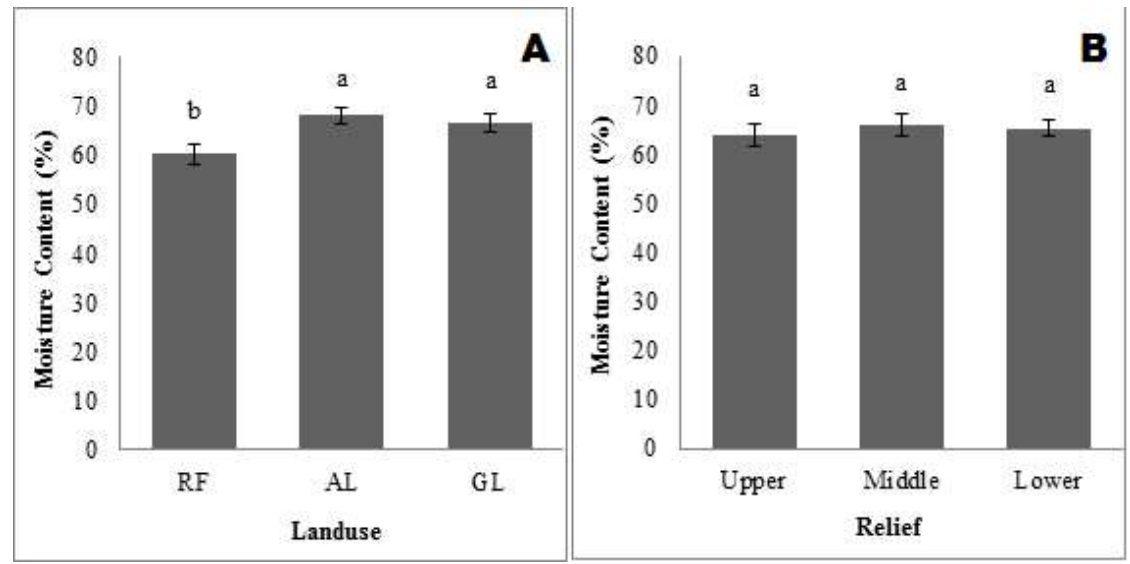

Figure 4. Soil moisture content at field capacity of the different land uses (A) at different reliefs (B) in Cienda, Gabas, Baybay City, Leyte. (Note: RF- Reforestation site; AL- Agricultural land; GL - Grassland. Different letter subscripts $(a-b)$ of the same dependent variable among land use and relief are significantly different at $p \leq 0.05, n=27$ ) 
Microbial Respiration as Indicator of Soil Quality

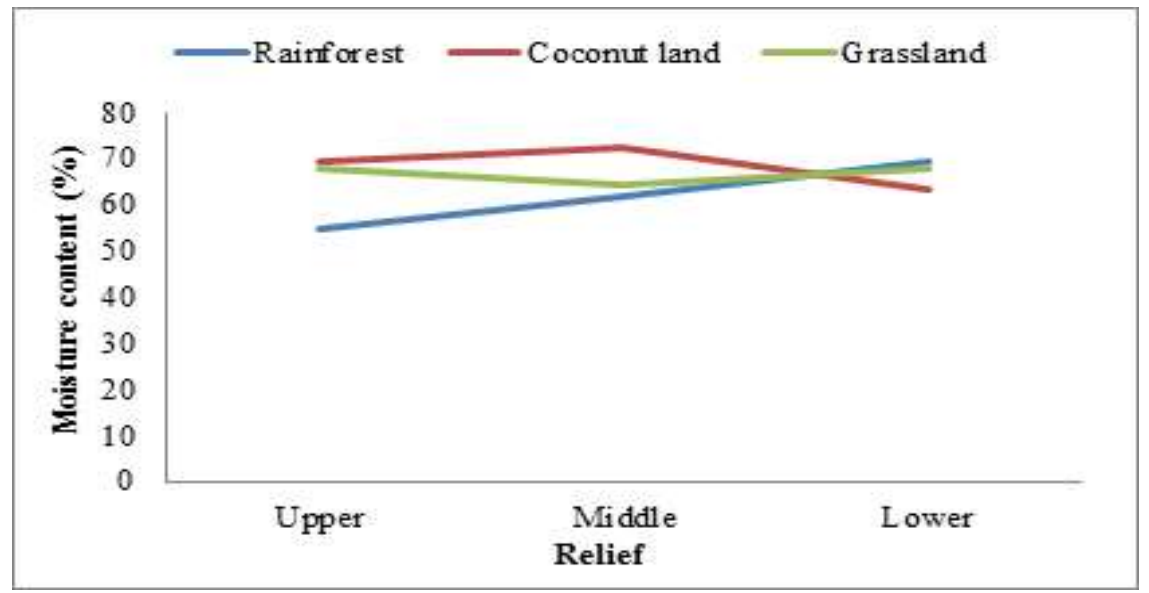

Figure 5. Two factor interaction effect of land use and relief on soil moisture content in Cienda, Gabas, Baybay City, Leyte

Soil texture affects water retention capacity of the soil. Clay tends to retain more moisture because of its density compared to sand and silt. Marohn (2007) reported that the Cienda reforestation site has a heavy clay soil texture. However, the significantly higher $(p=0.01)$ moisture content at field capacity of the soil under the agricultural land may indicate higher percentage of clay compared to the reforestation site. Another possible reason could be the water holding-properties of OM (Hadi et al 2001) that changes moisture content at field condition.

\section{Microbial Respiration of Different Land Uses}

Results revealed that evolved $\mathrm{CO}_{2}$ increased with increasing period of incubation. Data, however, suggest that the greatest production of $\mathrm{CO}_{2}$ occurred during the first day of incubation. The increased $\mathrm{CO}_{2}$ and the declining oxygen concentrations inside the sealed jars as the period of incubation increased could have possibly inhibited soil microbial activity (Batistel \& Asio 2008). In addition, this indicates that the substrate level decreased which consequently reduced the microbial respiration to negligible rates (Chapin et al 2002). Moreover, results show that throughout the three incubation periods, grassland had the highest microbial respiration rate among the three land uses as reflected by the evolved $\mathrm{CO}_{2}\left(91.32,97.10,100.50 \mathrm{mgCO}_{2}\right)$ while the reforestation site had the lowest (51.62, $64.02,68.97 \mathrm{mgCO}_{2}$ ) after one, three and seven days of incubation respectively (Figure 6). Throughout three incubation periods, a significant difference $(p=0.00)$ in microbial respiration between land uses was found.

Pearson correlation revealed that organic matter has a very strong negative correlation $(-0.911)$ with soil microbial respiration. This suggests an inverse relationship between the two parameters implying that as microbial respiration increases organic matter decreases. This means that faster decomposition results in the formation of less stable humus and an increased liberation of $\mathrm{CO}_{2}$ to the atmosphere, and a reduction in organic matter (Bot \& Benitez 2005). 


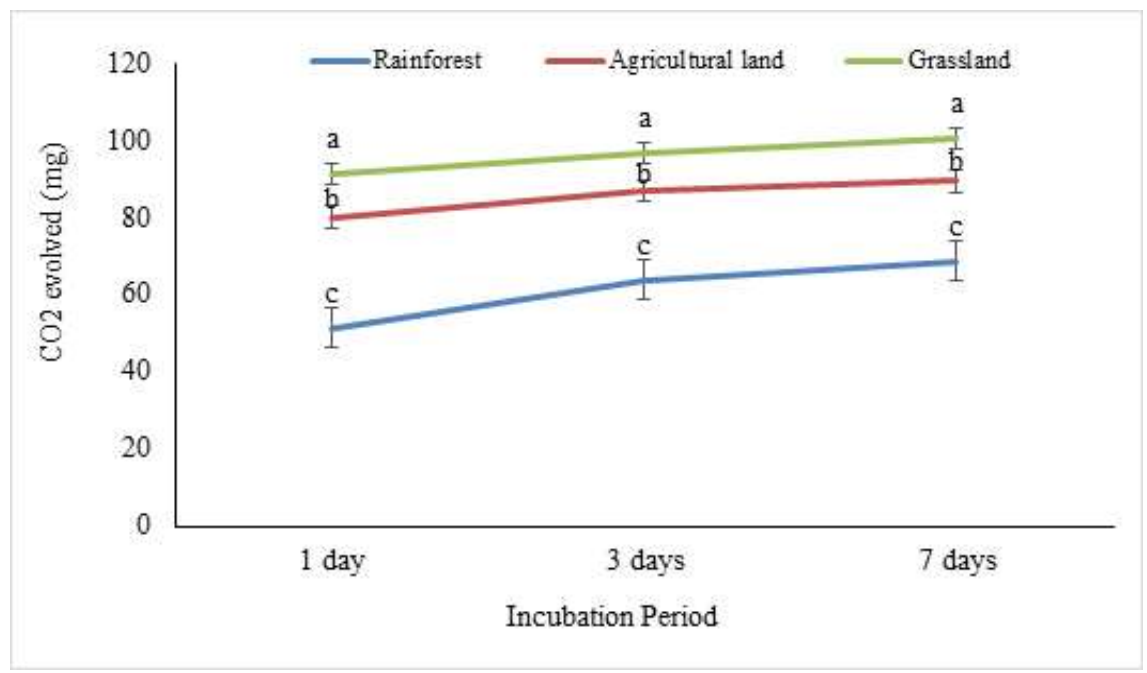

Figure 6. Microbial respiration in different land use types after incubation of soils from Cienda, Gabas, Baybay City, Leyte. (Note: Different letter subscripts (a-c) of the same dependent variable among land use are significantly different at $p \leq 0.05, n=28$ )

In addition, moisture content strongly influences microbial respiration with a correlation value of 0.537 which is highly significant at $a=0.01$. This suggests that microbial activity is enhanced as moisture content increases. This explains the results of this study wherein microbial respiration rate was consistently highest ( $91.32 \mathrm{mgCO}_{2} /$ day, $97.13 \mathrm{mgCO}_{2} / 3$ days, $100.56 \mathrm{mgCO}_{2} / 7$ days; standard error is \pm $2.75)$ in grassland ecosystem. This conforms to the statement of Davidson and Janssens (2006) that grassland soil has high $\mathrm{CO}_{2}$ evolution. Grassland is characterized by high moisture content at field capacity $(66.62 \pm 1.57)$ and fast turnover rate of carbon (Davidson \& Janssens 2006).

However, according to Curiel et al (2007), the most relevant factors affecting microbial respiration are temperature, soil moisture and carbon inputs. Although temperature was not measured on site, it is expected to be highest in grassland among the three land uses due to its nearly direct exposure to solar radiation relative to the two other land use types. Chapin et al (2002) stated that rising temperature causes an exponential increase in microbial respiration, speeding up the mineralization of organic carbon to $\mathrm{CO}_{2}$. Under reforestation site, soil temperature is expected to be relatively lower due to presence of the tree canopy which intercepts solar energy. This environmental condition could decrease the decomposition process in the reforestation site resulting to the accumulation of organic matter on the forest floor thus, higher OM content on its topsoil. 
Microbial Respiration as Indicator of Soil Quality

With respect to moisture content, moisture limitation can also reduce microbial activity and restrict microbial access to $C$ substrates (Wood et al 2013). The decomposition rate of mineral soil generally declines at soil moistures less than 30 to $50 \%$ of dry mass (Haynes 1986), due to the reduction in thickness of moisture films on soil surfaces and therefore the rate of diffusion of substrates to microbes (Stark \& Firestone 1995). However, decomposition is also reduced at high soil moisture contents (eg, greater than 100 to $150 \%$ of soil dry mass in mineral soils; Haynes 1986). Ideally, soil moisture enhances soil microbial respiration up to near field capacity, or when $60 \%$ of the pore space is filled with water (USDA-NRCS 2009). More than this, the ability of soil organisms to respire is negatively affected due to limiting oxygen availability. The moisture content obtained in different land uses falls on the values at which moisture content can facilitate microbial respiration. That is, in normal environment, grassland, having the highest moisture content, can still accommodate the highest possible microbial respiration and continuous decomposition of organic matter than the other land uses.

Across reliefs, microbial respiration also differs significantly after 1 day $(p=$ $0.01), 3$ days $(p=0.01)$ and 7 days $(p=0.00)$ incubation periods. This means that the amount of released $\mathrm{CO}_{2}$ increases significantly with increasing incubation period. However, results showed that lower and middle reliefs have no clear differences, but differ significantly with upper relief (Figure 7). This may be attributed by the different microbial biomass present at each topographic position. The interaction between land use types and reliefs also showed no significant effect on microbial respiration.

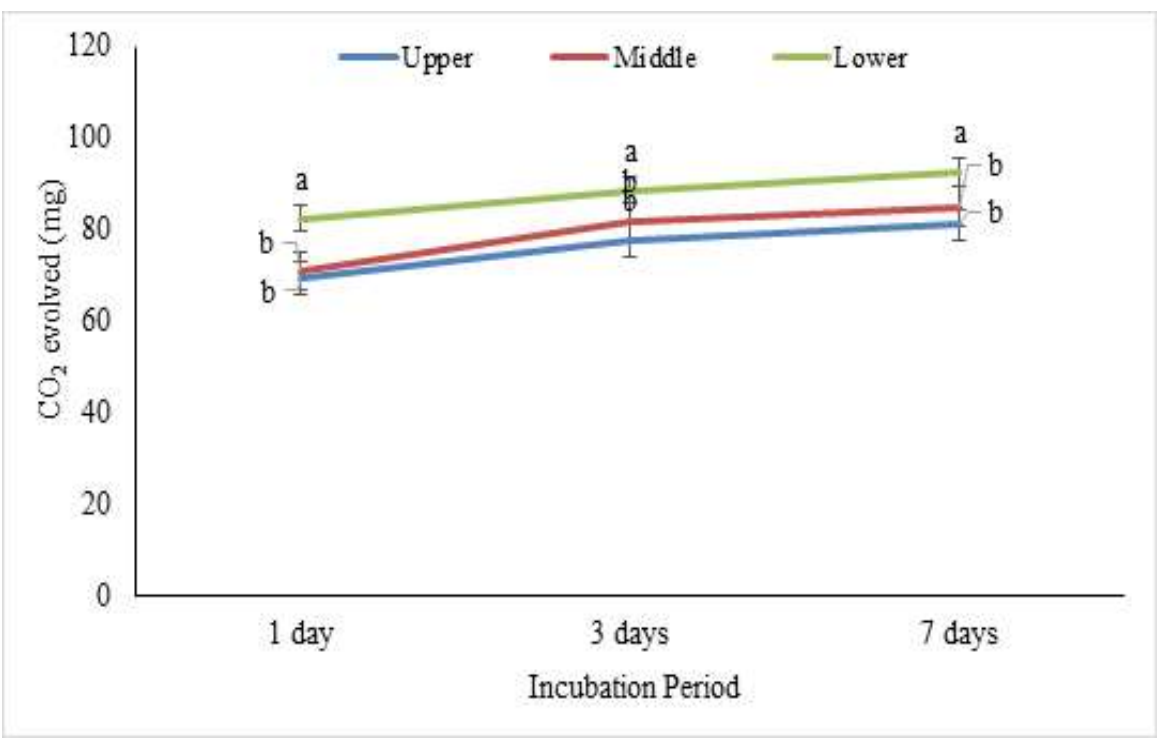

Figure 7. Microbial respiration at different topographic reliefs after incubation of soils from Cienda, Gabas, Baybay City, Leyte (Note: Different letter subscripts (a-b) of the same dependent variable among topographic relief are significantly different at $p \leq 0.05, n=28$ ) 


\section{CONCLUSIONS}

Among the soil properties tested, organic matter and moisture content significantly affects microbial respiration. Results suggest that soil organic matter decreases with increasing microbial respiration. Moisture content, on the other hand, enhances microbial respiration, however, up to near field capacity only. In addition, there is no clear difference in the effects of total nitrogen and soil pH on microbial respiration. Microbial respiration tends to vary significantly between land uses and across relief.

Among the three land uses, grassland has the highest microbial respiration rate while reforestation site has the lowest. There is no interaction between different land use types and across reliefs. Organic matter and moisture content are affected significantly by different land uses. Different relief also significantly affects organic matter. However, relief has no effect on moisture content. Results obtained show insignificant effect of different land uses and reliefs on total nitrogen and soil pH.

\section{REFERENCES}

Alexander M. 1977. Soil microbiology. Second edition. John Wiley and Sons, New York, New York, USA.

Anderson T. 2003. Microbial eco-physiological indicators to assess soil quality. Agriculture, Ecosystems and Environment, 98:285-293.

Asio VB. 1996. Characteristics, weathering, formation and degradation of soils from volcanic rocks in Leyte, Philippines. Hohenheimer Bodenkundliche Hefte 33, Stuttgart, Germany.

Asio VB, Jahn R, Stahr K \& Margraf J. 1998. Soils of the tropical forests of Leyte, Philippines II: impact of different land uses on the status of organic matter and nutrient availability. In Schulte A and Ruhiyat D (eds), Soils of Tropical Forest Ecosystems (pp37-44). Springer-Verlag, Berlin.

Batistel CC \& Asio VB. 2008. Effects of Leaf decomposition of selected exotic and native tree species on forest soil quality. Annals of Tropical Research 30(1):29-39.

Bot A \& Benites J. 2005. The importance of soil organic matter: key to droughtresistant soil and sustained food production (No. 80). Food and Agriculture Organization, Rome.

Chapin SF III, Matson PA \& Mooney H. 2002. Principles of Terrestrial Ecosystem Ecology (p398). Springer-Verlag, Inc., New York.

Curiel Y, Baldocchi JDD, Gershensonz A, Goldstein A, Misson L \& Wong S. 2007. Microbial soil respiration and its dependency on carbon inputs, soil temperature and moisture. Global Change Biology, 13:1-18.

Davidson EA \& Janssens IA. 2006. Temperature sensitivity of soil carbon decomposition and feedbacks to climate change. Nature, 440:165-173.

Food and Agriculture Organization of the United Nations. 2005. The importance of soil organic matter: Key to drought-resistant soil and sustained food and production. FAO Soils Bulletin 80.

Hadi PE, Inubushi KY \& Furukawa A. 2001. Seasonal changes of $\mathrm{CO} 2, \mathrm{CH} 4$, and N2O fluxes in relation to land-use change in tropical peatlands located in coastal area of South Kalimantan. Chemosphere, 52: 603-608. 
Microbial Respiration as Indicator of Soil Quality

Haynes RJ. 1986. Mineral Nitrogen in the Plant-soil System. Academic Press, Toronto.

Hoorman JJ \& Islam R. 2010. Understanding Soil Microbes and Nutrient Recycling. Agriculture and Natural Resources. Ohio State University.

International Soil Research and Information Center (ISRIC). 1998. Procedures for Soil Analysis (p106). The Netherlands, Wageningen.

Jackson ML. 1958. Soil Chemical Analysis (p498). Prentice Hall Inc., Englewood Cliffs, New Jersey.

Magdoff F \& Van ES H. 2001. Building Soils for Better Crops (2nd edn). Sustainable Agriculture Network, Beltsville, MD.

Marohn C, Jahn R \& Sauerborn J. 2006. Soil biological activity under different land uses in Leyte, Philippines. Annals of Tropical Research, 28:1-13.

Marohn C. 2007. Reforestation farming on Leyte island, Philippines - aspects of soil fertility and carbon sequestration potential (PhD dissertation). University of Hohenheim, Germany.

Pankhurst CE, Doube BM \& Gupta VV. 1997. Biological indicators of soil health: Synthesis. In Pankhurst CE, BM Doube BM \& Gupta VVSR (eds), Biological Indicators of Soil Health (pp419-435). CAB International, Wallingford.

Philippine Coconut Authority. Accessed online on 22 September 2017 from http://pca.da.gov.ph/index php/2015-10-26-03-15-57/2015-10-26-03-22-41.

Stark JM \& Firestone MK. 1995. Kinetic characteristics of ammonium-oxidizer communities in a California oakwoodland-annual grassland. Soil Biology \& Biochemistry,28: 1307-1317.

Toth JA, Nagy PT, Krakomperger Z, Verea Z, Kotroczo Z, Kincses S \& Papp M. 2011. Effect of litter fall on soil nutrient content and $\mathrm{pH}$, and its consequences in view of climate change (Síkfökút DIRT Project). Acta Silvatica et Lignaria Hungarica, 7:75-86.

Turner MK \& Burns IG.2001. Fate of nitrogen from crop residues as affected by biochemical quality and the microbial biomass. Soil Biology \& Biochemistry 30:2055-2065.

Wolters V \& Schaeffer M. 1994. Effects of acid deposition onsoil organisms and decomposition processes. In Benckiser G.(ed), Effects of Acid Rain on Forest Processes (pp83-127). Wiley, NewYork.

Wood TE, Detto M \& Silver WL. 2013. Sensitivity of soil respiration to variability in soil moisture and temperature in a humid tropical forest. PLOSONE 8(12):

United States Department Of Agriculture-Natural Resources Conservation Service. 2009. Soil quality indicators: Soil respiration. United States of America. 